\title{
MARKING SACRED GROUND THROUGH IMPORTED TREES AND MEDIEVAL EUROPEAN SCULPTURE AT THE WASHINGTON NATIONAL CATHEDRAL
}

\author{
Nathan HEAVERS
}

Virginia Polytechnic Institute and State University, USA

\begin{abstract}
The landscape of the Washington National Cathedral contains a variety of sacred objects imported from Europe and Asia. They include stone sculptures and living flora. Many of the stone objects came from the collection of George Grey Barnard, an American sculptor, trained in Paris, who travelled Europe in the early $20^{\text {th }}$ century purchasing medieval antiquities (Weinberger, 1941). How do we understand these displaced pieces incorporated into this new context? On the one hand, their use in the landscape brings it significance, a physical and tangible connection to the roots of Christianity. On the other hand, they remind us of the relative youth of this sacred landscape and the question of what makes places sacred. Is a place sacred because of something inherent to it or do we mark ordinary ground with significant objects to sanctify it? Largely, the Washington National Cathedral landscape seems to demonstrate the latter approach. Imported objects mark and validate the sacredness of the site from medieval stone archways to significant pairs of trees.
\end{abstract}

Keywords: Washington National Cathedral, sacred ground, George Grey Barnard, sacred trees, medieval sculpture

The project of the Washington National Cathedral commenced in the 1890s. Its construction coincided with a period of considerable American interest in Europe architectural precedents, especially the Gothic (Clark, 1973). It is the work of the private Protestant Episcopal Cathedral Foundation with no government funding. The intent was to create a great cathedral for the nation, a freestanding masonry structure that took 83 years to complete and is now undergoing repairs after a 2011 earthquake. Preceding and during its construction, a variety of smaller monuments and plantings around its grounds set the stage for the century long project. A natural amphitheatre in an oak grove, a peace cross, a baptistery and a small sanctuary, all preceded the laying of the cathedral's cornerstone in 1907 (Satterlee, 1901). These objects and buildings began to mark the landscape as a sacred ground. Frederick Law Olmsted Jr. laid out the overall landscape, including the Bishop's Garden to the south of the cathedral and a native oak grove, which he preserved at the core of the site (Figure 1). Into these spaces the All Hallows Guild, a group of volunteer women, and the cathedral staff, added various medieval artefacts, along with religiously significant plants, to build associations between the place and Christian traditions (Bratenahl, 1929). By staking out the hilltop with medieval objects, the cathedral's creators made the place sacred, turning a hilltop farm and woods into a sanctuary and a site of pilgrimage. This method of sanctifying the land supports J.B. Jackson's claim that in America we shape and add to places in order to make sites sacred (Jackson, 1980). This is in contrast to the older European way, which understood places as sacred first with their genius loci (Nilsson, 1948). Of course, the cathedral grounds and its groves had a special quality and were understood by some as sacred (Heavers, 2018), as evidenced by Christian gatherings among its oaks. However, the dominant means of establishing sacredness was to add imported objects, creating exterior spaces of devotion. The objectives of this study are to:

- inventory the imported objects (trees and sculptures)

- analyse how they mark the grounds

- explain the extent to which they shape sacred space

\section{Material and methods \\ The situation and materials of the cathedral landscape}

The Washington National Cathedral landscape is 23 hectares on a wooded hill about $100 \mathrm{~m}$ above sea level overlooking the city. It is in the Piedmont region of the East Coast of the United States and in the Potomac River watershed. The focus of the study is on the south side of the cathedral grounds, including the enclosed Bishop's Garden, the Pilgrim Steps, the outdoor amphitheatre, and the Olmsted Woods (Figure 1). The natural situation, the ridgeline of the hilltop, was suitable for the construction of a cathedral, but the emphasis here is on the materials imported or brought to the site. The landscape and its artefacts are a living collection and perform as an outdoor history museum. History museums were increasingly popular cultural institutions in late $19^{\text {th }}$ and early $20^{\text {th }}$ century America (Wallace, 1981). It was typical for institutions like the National Cathedral to underscore their identities with historical collections.

Contact address: Nathan Heavers, Virginia Tech, 1001 Prince Street, Alexandria, Virginia, USA, 22314, tel: 01-202-302-7951, e-mail: heavers@gmail.com 


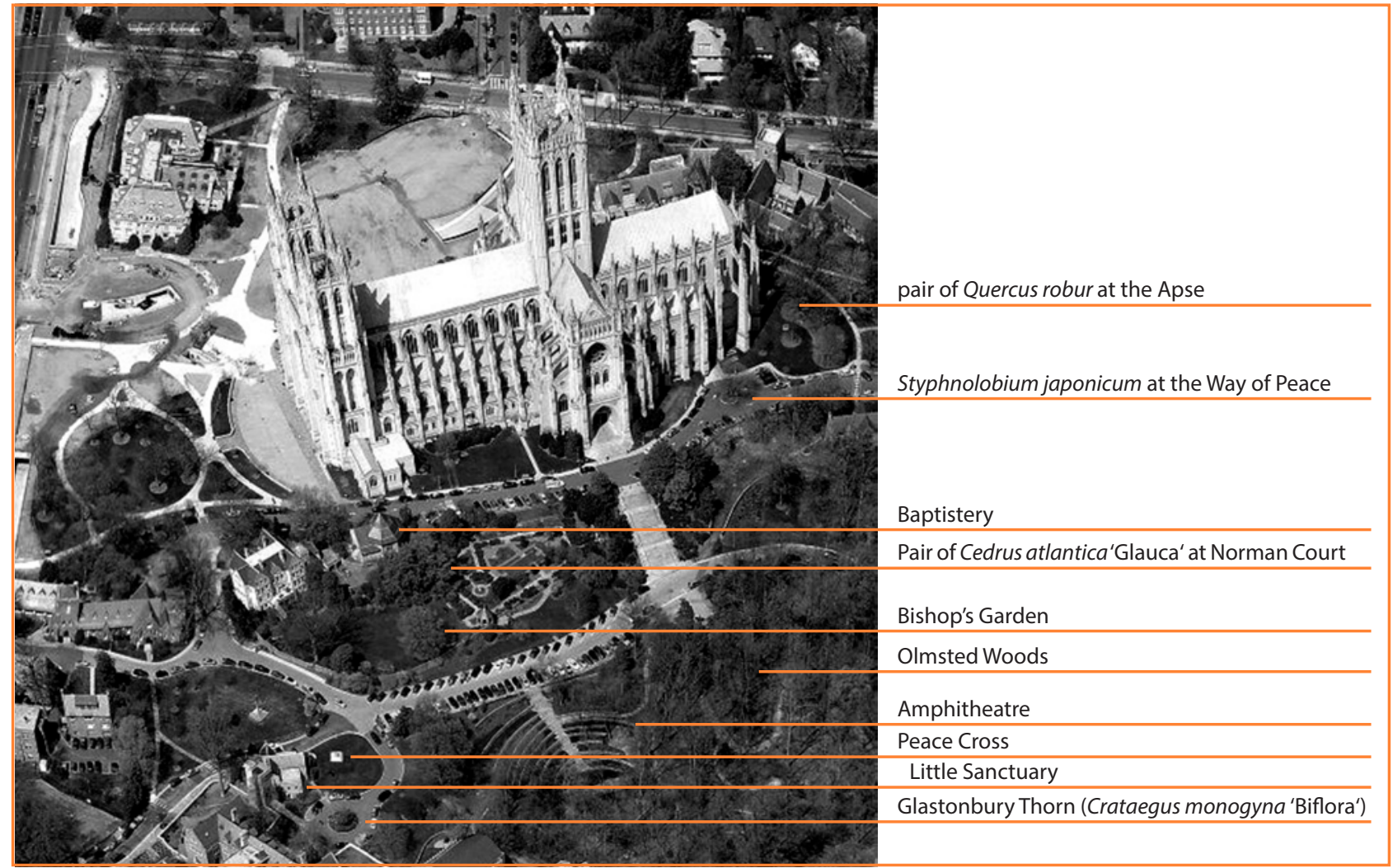

Figure 1 The landscape to the south of the Washington National Cathedral designed by Frederick Law Olmsted Jr. Base image from Bing aerials Photo: by author

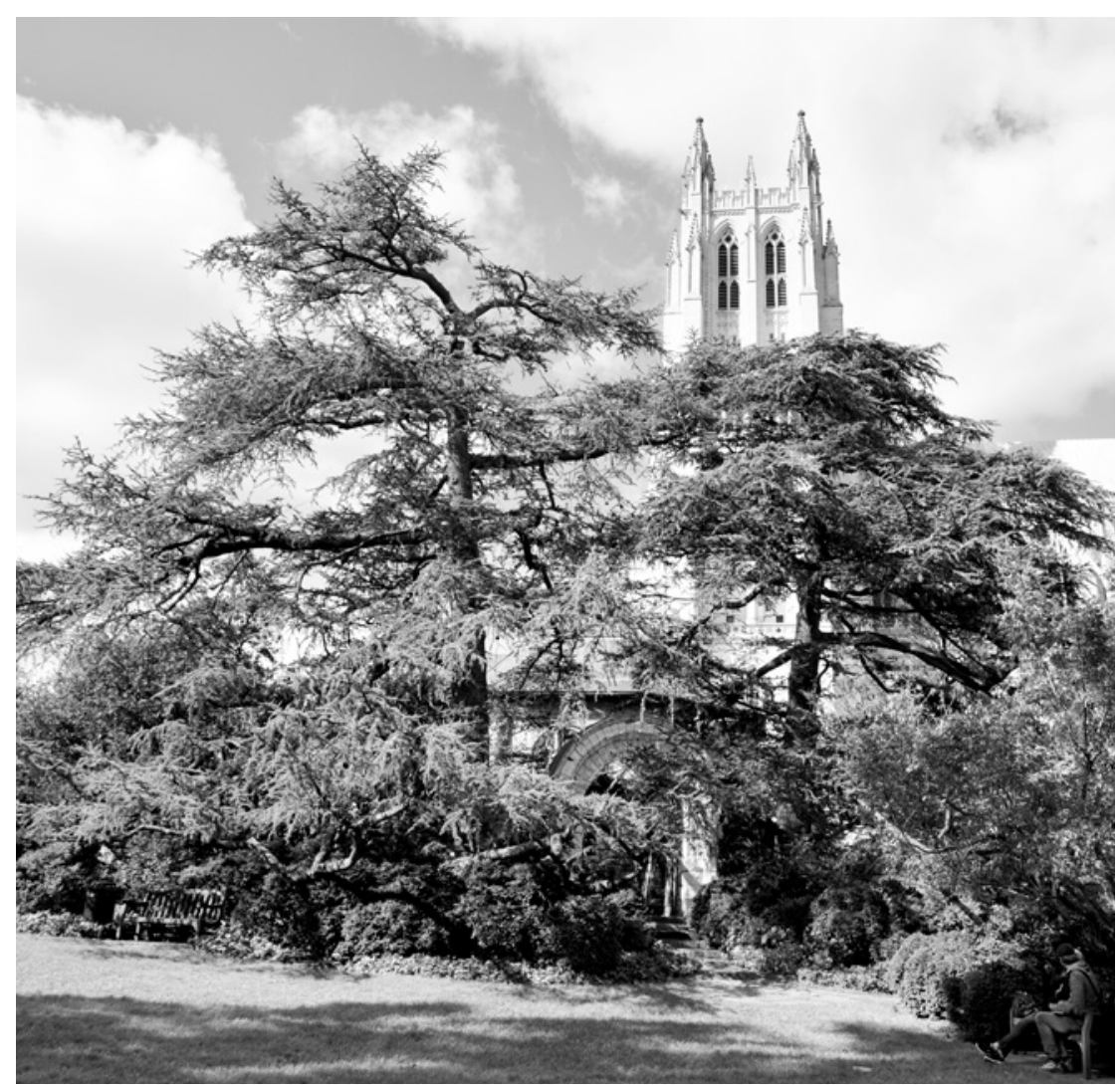

Figure 2 Pair of Cedrus atlantica 'Glauca' from Palestine planted in 1902 before cathedral cornerstone Photo: by author
Historical analysis of the grounds

The historical portion of this study interprets available maps, plans, photographs, letters, and pamphlets from the Cathedral Archives, the Smithsonian Institution, and the All Hallows Guild. This research draws on the approach of material culture studies, as exemplified by James Deetz (1977), who used artefacts to interpret history. Several useful texts cover the history of the construction of the cathedral, beginning with Satterlee's The Building of a Cathedral (1901). Florence Bratenahl's A Cathedral Hillside and its Gardens is the most significant historical publication for this analysis because it documents the George Grey Barnard sculptures in the landscape.

\section{Current analysis of artefacts in the cathedral landscape}

Field study and inventory in conjunction with historical records are the methods of analysis. The elements analysed include imported (non-native) trees that have sacred meaning and medieval architectural stone fragments from the collection 
of George Grey Barnard (All Hallows Guild, 2018). Important to this study are the relationships between the imported fragments and the overall design and layout of the cathedral and its gardens. The emphasis is on how in particular the artefacts mark the grounds to create sacred space. The study reveals three types of marking:

1. single trees and pairs of trees in partnership with important buildings and structures on the grounds,

2. standalone stone objects in the landscape, such as crosses,

3. architectural fragments incorporated into the landscape's walls.

\section{Results and discussion}

While there are numerous memorial trees dedicated to significant individuals across the cathedral's grounds, four specific plantings serve to illustrate how imported trees mark out sacred ground. 1) A pair of Cedrus atlantica 'Glauca' grow in the Bishop's Garden (Figure 2). Henry Yates Satterlee, the founding Bishop of Washington, had two trees brought from Palestine by steam ship to represent cedars of Lebanon (Washington National Cathedral, 2016). Planted in 1902 , they pre-date the cornerstone of the cathedral, and exemplify one of the first acts of differentiating this ground from ordinary land. 2) A few years later, as construction began on the apse, two Quercus robur, English oak, joined the cedars. Growing alongside the flying buttresses, these two European trees witnessed the importation of gothic architecture to America, and mediated between it and the native oak forest. 3) Southwest of the cathedral, in front of St. Alban's School, is another European import, grown from a cutting of the Glastonbury Thorn (Crateagus monogyna 'Biflora'). Legend has it that the original tree grew from Joseph of Arimathea's staff, which he drove into Wearyall Hill in Glastonbury, England. It blooms twice annually - once thought to be a miracle. Just as Joseph of Arimathea brought Christianity to England, this tree symbolizes spreading the gospel to America. 4) Along the south side of the cathedral, near the Way of Peace entrance is a Styphnolobium japonicum or Japanese pagoda tree named for its association with Asian temples. One might interpret it as a reminder of the idea that the national cathedral is "a house of prayer for all people," and opens its doors to visitors of all faiths. Together these trees represent some of the ancient stock of sacred plants with associations to Christian, Jewish, and other religions. Using these and other species as key features of the landscape increased its connection to religious traditions thereby sanctifying the landscape.

Similar to the trees, there are now numerous sculptures, plaques, and memorials throughout the cathedral grounds. However, the collection of pieces from George Grey Barnard, acquired in the 1920s and 1930s (Bratenahl, 1929), stand out because of their age and the way that they give religious authenticity to the grounds. These additions strived to make significant an otherwise very new project and not long sacred site. There are two sorts of medieval pieces used those that mark garden rooms, acting as focal points in the design and those incorporated into walls, framing rooms.

Of the focal point type, there are two that are chief components of the Bishop's Garden - the Wayside Cross and the Carolingian Font (Figure 3). The Wayside Cross is an early Christian marker of the sort used to guide pilgrims throughout Europe. It rests at the centre of the garden. The $9^{\text {th }}$ century Carolingian Font, a baptismal font, comes from the Abbey of St. Julie in the Aisne. It sits in the middle of the Hortulus, an herb garden of European plants from Charlemagne's plant list. In line with the Wayside Cross, the two pieces demarcate the main axis of the garden. Other standalone objects include two $13^{\text {th }}$ century capitals - one Cluny from used as a birdbath, and the other from a monastery near Rheims now a sundial. Other medieval pieces are set within the walls of the garden and form important entrances. The main entrance to the garden is a copy of a $12^{\text {th }}$ century Norman arch. The original deteriorated so much between 1928 and 1978 that a replica in Indiana limestone replaced it. A second $12^{\text {th }}$
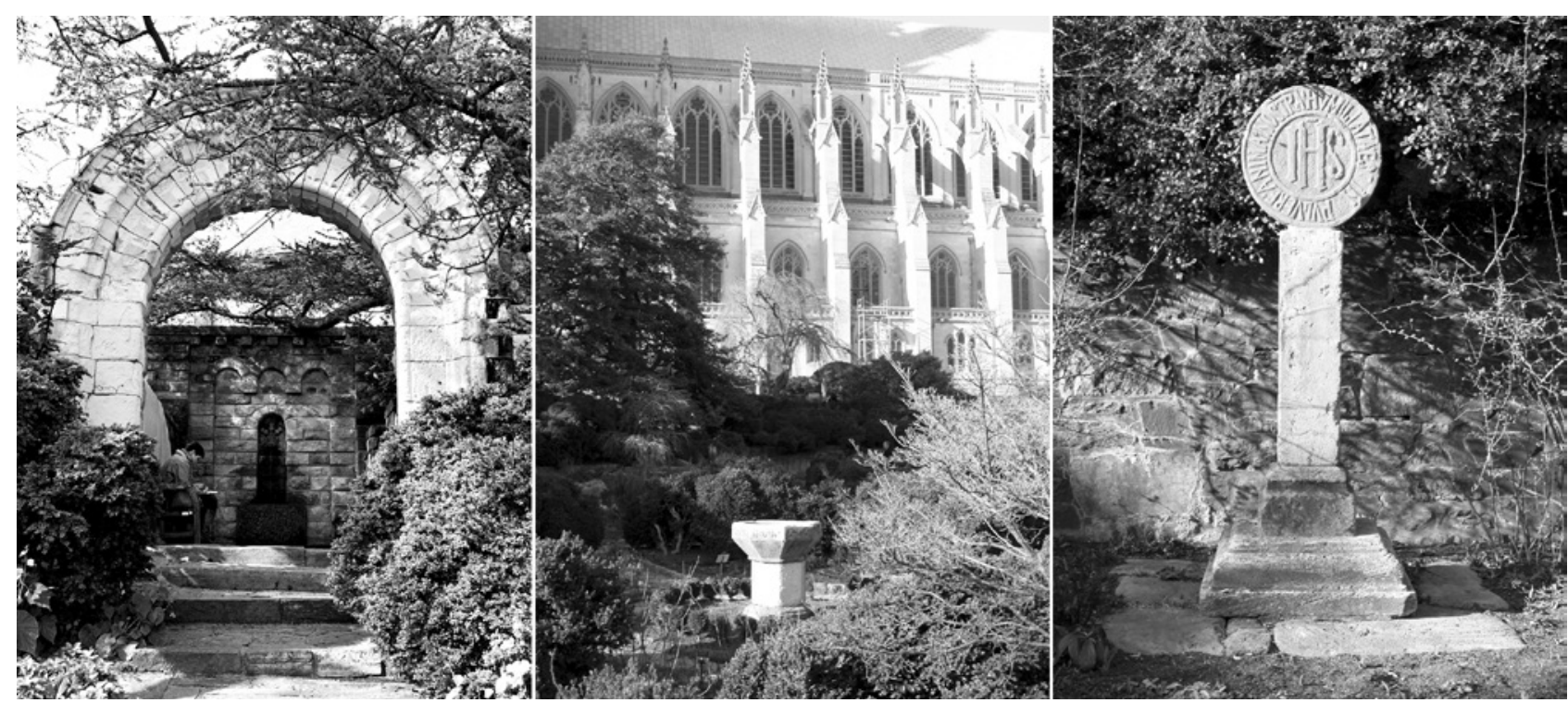

Figure 3 Norman Court (left), Carolingian Font (middle), and Wayside Cross (right) Photo: by author 
century Norman Arch in its original state creates a portal into the Norman Court (Figure 3) between and under the pair of Cedrus atlantica 'Glauca' planted in 1902. Embedded in the local sandstone walls of the open-air court is a $15^{\text {th }}$ century bas-relief sculpture of Christ with Mary and John. Three other bas relief sculptures give spiritual weight to a long retaining wall above a perennial border, including the figure of St. Catherine above a small pool on the west end of the border. On the east end of the Bishop's Garden, near where the 2011 earthquake shook a pinnacle from the central tower, the Finial Garden room contains that artefact. It strangely continues the precedent of including fragments in the garden, but this time the artefact is from the $20^{\text {th }}$ century cathedral itself.

The combination of tree plantings and medieval stone fragments incorporated in the landscape mimic the type of small sacred spaces found along the wayside on pilgrimage routes in Europe and the Holy Land. While the whole project seems to borrow somewhat too deliberately, trying to make a place sacred with historic sculpture and important trees, it is a universal practice to re-purpose past works and ideas. Furthermore, it is noteworthy how the Washington National Cathedral uses artefacts as though made for that landscape, taking some preservation measures, but the stones, like the trees, are part of a whole and gradually changing composition.

\section{Conclusion}

As these Christian markers age and the Washington National Cathedral acquires its own patina, they remind visitors of the significance of small gestures on the land and their potential to connect people through ideas and faith across continents. If we understand the trees and imported stones as markers, incorporated into a foreign setting to give it sacred value, this is a universal practice. However, the practice is distinctive in the context of establishing a cathedral in America and it shows how much deference the cathedral's creators and benefactors had for European medieval architecture and pre-Reformation Christian traditions. One might also view the Washington National Cathedral as a nationalistic project.
Even though it did not receive government funding and, in principle, the United States has a separation of church and state, it supports state ceremonies and therefore promotes an Anglican version of Christianity. Not surprisingly, this version of Christianity promotes the use of objects as religious symbols, supporting the thesis that these imported objects aimed to sanctify the ground, though we may debate how successfully and to what ends.

\section{References}

ALL HALLOWS GUILD. 2018. Fountains, Statuary, Plaques. Retrieved from https://allhallowsguild.org/the-grounds/fountains-statuaryplaques/ on Oct. 10, 2018.

BRATENAHL, F. 1929. A Cathedral Hillside and its Gardens. Washington, DC : All Hallows Guild, 1929.

CLARK, K. 1973. The Gothic Revival: an essay in the history of taste. London : Murray, 1973.

DEETZ, J. 1977. In small things forgotten: The Archaeology of Early American Life. New York : Doubleday, 1977.

HEAVERS, N. 2018. The Olmsted Woods: A hybrid approach to creating sacred groves at the Washington National Cathedral. In European Council of Landscape Architecture Schools Conference Proceedings, Belgium: University College Ghent, 2018, pp. 310-316. JACKSON, J.B. 1980. The Necessity for Ruins and Other Topics. Amherst : The Univeristy of Massachusetts Press, 1980.

NILSSON, MP. 1948. Greek Piety. Translated by Herbert Jennings Rose. Oxford: Clarendon Press, 1948.

SATTERLEE, H.Y. 1901. The Building of a Cathedral. Washington, DC : Byron S. Adams, 1901

WALLACE, M. 1981. Visiting the Past: History Museums in the United States. In Radical History Review, 1981, no. 25, pp. 63-96.

WASHINGTON NATIONAL CATHEDRAL. 2016. For the Ages. Cathedral Age. Retrieved from https://cathedral.org/cathedral-age/ for-the-ages/ on Oct. 7, 2018.

WEINBERGER, M. 1941. The George Grey Barnard Collection Catalogue. New York : Privately published by Robinson Galleries, inc., 1941 